\title{
Secure Parental Attachment and Deviant Behaviour Among Secondary School Students in Homabay County-Kenya
}

\author{
Dorothy Anyango Aute \\ Department of Psychology, Masinde Muliro University of Science and Technology, Kakamega, Kenya
}

Email address:

auteagai@yahoo.com

To cite this article:

Dorothy Anyango Aute. Secure Parental Attachment and Deviant Behaviour Among Secondary School Students in Homabay County-Kenya. Science Journal of Education. Vol. 7, No. 6, 2019, pp. 127-133. doi: 10.11648/j.sjedu.20190706.13

Received: October 5, 2019; Accepted: November 5, 2019; Published: December 4, 2019

\begin{abstract}
For any learning institution to achieve its goals successfully, it is paramount that all members adhere to the norms of the institution which may be written or not. Problems arise in schools when some students fail to conform to the school rules and ergo disrupt the normal routine of the system. In Kenya, despite efforts by the government to curb indiscipline in schools, student deviance has been persistent in our schools since the first case of student unrest was reported in 1908. These behaviour cause destruction of property in schools, death, some students dropping out of school, physical injury to both the teachers and the students, psychological disturbances to both the students and the teachers and finally poor academic performance. This study assessed the relationship between secure parental attachment style and deviant behavior among secondary school students in Homabay County. The study was guided by attachment theory by John Bowlby and Mary Ainsworth which provided a conceptual link between parent adolescent relationship and deviance. The study employed quantitative research method and a correlational survey research design. The study population consisted of form two students from all the secondary schools in Homabay County. Out of the population of 20,160 students a representative sample of 512 students was randomly sampled. Data was collected using questionnaires. Validity of these instruments was ascertained through expert judgment and piloting while the reliability of the study was tested using the split half method and the level of confidence was $\alpha \leq 0.05$. Data was analyzedusing both descriptive and inferential statistics. The findings revealed a significant negative relationship between secure parental attachment and deviant behavior $(\mathrm{r}=-0.633, \mathrm{p}<0.05)$.
\end{abstract}

Keywords: Secure Parental Attachment Style, Deviant Behavior, Secondary School Students

\section{Introduction}

The sole purpose of education is to impart appropriate skills, values, attitudes, knowledge and competencies into the learners and consequently see the learners excel academically. This is realized through the designed rules and regulations meant to aid students in conforming to the dominant norms of the society. However, problems arise when some students fail to abide by the laid down rules of the schools. According to Mbuthia [15] deviant behavior is an uncommon behaviour, different from the norm and does not conform to what society expects. Deviance among secondary school students is a challenge since it leads to destruction of learning facilities, physical injuries, deaths, early pregnancies, HIV/AIDS infection and finally poor academic performance.

According to Bowlby [5] attachment is a long lasting psychological connection with a meaningful person that causes pleasure and soothes in times of stress. It is a tendency to seek closeness to another person and feel secure when that person is present. Traditionally, home is the place where behavior is shaped and it is the role of the parents to make sure that the child goes to school already imbued with a sense of right and wrong. This can only happen when there is an appropriate attachment between the parent and the child right from conception through adolescence. Without this attachment, the child is likely to become deviant and hence perform poorly in school.

Deviance among adolescents has been a problem world over. According to The Elton Report (1989), deviance was already a big problem in Britain by 1989 and this necessitated the formation of the Elton task force. Parks [24] avers that adolescents in the United States are increasingly getting involved in criminal activities thus creating problems 
for parents, schools and the community as a whole. Harrison [11] also opines that in the year 2011, 64 cases of homicide, 58 instances of rape, 893 reports of robbery and almost 1500 counts of aggravated assault were reported in Florida. All these cases constituted violent crime with most of the offenders being the youth. In Taiwan, instances of deviant behavior have become more serious, the most common being the cases of students bullying others and students threatening teachers in public [8]. The trend in Africa is not different as research in most African countries has shown that deviance among youths in Africa is a matter of great concern. For example, Ethiopian young people aged 10-24 have emerged as a segment of the population most vulnerable to a broad spectrum of serious sexual health problems [35]. Ekpo and Ajake [10] reported that in Nigeria there is a high rate of complaints about students' delinquency.

In Kenya, the history of deviance dates back to 1908 when the first case of students' unrest in secondary schools was reported. In Homabay County deviance has been rampant in the schools as indicated by the high number of cases of deviance reported in the region. Between the years 2018 and mid 2019, 60 cases of deviance were reported from the 315 schools within the region (Homabay County Education Office, 2019). This led to destruction of property, students dropping out of school, physical injury and poor academic performance within these schools. This problem is further aggravated by the fact that nobody seems to have a conclusive explanation as to why the adolescents behave the way they do and how to get rid of deviance. The insufficient research on deviance among adolescents in Homabay County may have serious implications on the success of any interventions geared towards curbing deviance in this region. Further research on deviance could unravel the puzzle of student deviance in secondary schools. This study focused on riskysexual behavior, violence and drug use as some of the deviant behaviors exhibited among the students in schools within Homabay Coonty.

\section{Research Methodology}

This study employed quantitative research method and a correlational study design. The target population in this study consisted of form two students from the 315 public and private secondary schools within Homabay County with a total population of 20,160 (11,752 boys and 8,408 girls) this population constituted 27 girls' schools, 35 boys' schools and 253 mixed day and boarding secondary schools (Homabay County Education Officer, 2019). The form two students were chosen to form the target population because they are at the peak of adolescence and most of the cases of deviance are found among these students. Given that Homabay County leads in HIV/AIDS infection in the country, second in teenage pregnancy coupled with the high rate of indiscipline cases reported within the county, it is necessary that a thorough investigation is carried out in this region in order to come up with a conclusive solution to deviance. The sample size was determined using the following formula.

$$
n=\frac{N}{1+N(e)^{2}}
$$

Decide on the margin of error. According to Mugenda and Mugenda [21] the margin of error is the statistical concept which expresses the discrepancy between the population and the characteristics of the sample, although the sample is drawn from that population. The confidence level for this study was at $95 \%(0.95)$. If any sample is selected 100 times, at least $95 \%$ of the samples will represent the characteristics of the population [25]. The margin of error for this study was therefore $5 \%$. The standard normal deviation at $95 \%$ is 1.96 (z value).

Sample proportion $(\%)=512 / 5120 \times 100=10.00 \%$

Girls boarding schools were $27 / 315 \times 100=8.57 \%$

Boys' boarding schools $35 / 315 \times 100=11.11 \%$

Mixed day and boarding schools $253 / 315 \times 100=80.31 \%$

Girls' schools $=8.57 / 100 \times 512=44$ students

Boys' schools $=11.11 / 100 \times 512=57$ students

Mixed day and boarding $=80.31 / 100 \times 512=411$ students

Where $\mathrm{n}=$ sample, $\mathrm{N}=$ the size of the population and $\mathrm{e}=$ the margin error.

Total 512 students

This is further captured in table 1 and table 2.

Table 1. Sample matrix for respondents.

\begin{tabular}{lllll}
\hline Sample unit & Sampling design & $\begin{array}{l}\text { Target } \\
\text { population }\end{array}$ & $\begin{array}{l}\text { Sample } \\
\text { size }\end{array}$ & Percentage \\
\hline Schools & Random sampling & 80 & 8 & $10 \%$ \\
Principals & Purposive sampling & 80 & 8 & $10 \%$ \\
HOD G\&C & Purposive sampling & 80 & 8 & $10 \%$ \\
PA & Purposive sampling & 80 & 8 & $10 \%$ \\
Deputy & Purposive sampling & 80 & 8 & $10 \%$ \\
principals & Random sampling & 5,120 & 512 & $10 \%$ \\
Students & & & & \\
\hline
\end{tabular}

Table 2. Sample matrix for schools.

\begin{tabular}{lllll}
\hline $\begin{array}{l}\text { School } \\
\text { type }\end{array}$ & Sampling design & $\begin{array}{l}\text { Target } \\
\text { population }\end{array}$ & $\begin{array}{l}\text { Sample } \\
\text { size }\end{array}$ & Percentage \\
\hline Boys & Stratified sampling & 9 & 1 & $11.11 \%$ \\
Girls & Stratified sampling & 7 & 1 & $8.57 \%$ \\
Mixed & Stratified sampling & 64 & 6 & $80.31 \%$ \\
Total & & 80 & 8 & $100 \%$ \\
\hline
\end{tabular}

Primary data was obtained from students. Parental attachment questionnaires were used to measure secure parental attachment style, deviant behavior variety scale was used to measure violence and drug use while Interest, Emotions and Relationships Scale was used to measure irresponsible sexual behavior.

The study adapted and piloted the 'People in My Life' scale (PIML) from the Inventory of Parent and Peer Attachment (IPPA) developed by Armsden and Greenberg (1987) to measure the students' perceptions of their relationships with parents. Given that PIML was originally designed to measure 10-12 years old children's perception of their relationships with parents, using it in this study ensured better student understanding and also enhanced the likelihood of obtainingvalid results. The responses rangedfrom almost 
never or never true to almost always or always true.

The study also adapted and piloted the DBVS [33] to measure deviance except irresponsible sexual behavior which was measured using a different instrument. The DBVS was designed to be used among adolescents aged between 12-19 years old. Some adjustments were done to this instrument in order for this scale to suit the sample of this study. Each question in the questionnaire was developed to address a particular aspect of deviance investigated in this study. The construct validity and factor validity test of the DBVS showed adequate goodness of fit indices for both models. The correlation between serious and minor infractions in the two factor model was very strong $(\mathrm{r}=0.895, \mathrm{p}<0.001)$, suggesting the absence of discriminant validity [33].

To measure dimensions of sexuality in adolescence, the sexuality scale, interests, emotions and relations scale (IERS) was used. This scale measures three significant aspects of sexuality in early adolescence. These three dimensions include: going out with someone, evaluating engaging in sexuality and the intensity of sexualization of relationships (cuddling, kissing, sexual intercourse e. t. c) e. g I have already had sex with a boy or a girl, giving priority to, measuring the need to be in love or not to have sex (emotional dimension) (for example, I plan to wait to find someone I love before having sex). A preference for sexual relationship involving affection is considered as a more integrated attitude in relation to sexuality. And (3) 'Flirting with the aim of having sexual relations, evaluating the desire or intension to be sexually active (for example, I plan to have sex as soon as the opportunity arises).

\section{Results and Discussions}

\subsection{Questionnaire Return Rate}

The study achieved $100 \%$ response return rate of students in all the questionnaires and all the questions in the questionnaires were answered. This was achieved because the researcher administered the instruments to each respondent to ensure that each and every respondent took part in the study.

\subsection{Secure Parental Attachment Style}

The students were probed on their parents' attachment styles. From the responses provided by the students on their parents' attachment styles, 219 out of 512 students indicated that their parents had secure attachment style The students' response on the parental attachment scale was as captured in table 3.

Table 3. Secure Parental Attachment Style.

\begin{tabular}{llll}
\hline Descriptive statistics & & Mean & Std. Deviation \\
\hline My parents respect my feelings & N & .831 \\
My parents accept me as I am & 512 & 2.70 & .672 \\
I trust my parents & 512 & 3.20 & .742 \\
My parents listen to what I have to say & 512 & 3.10 & .842 \\
My parents care about me & 512 & 2.51 & .703 \\
I can count on my parents to help me when I have a problem & 512 & 3.27 & .837 \\
My parents can tell when am upset about something & 512 & 3.02 & .901 \\
I talk to my parents when I have a problem & 512 & .944 \\
If my parents know that something is bothering me, they ask me about it & 512 & 2.74 & .965 \\
I share my thoughts and feelings with my parents & 512 & 2.85 & .909 \\
When I am away from home my parents know where I am and who I am with & 512 & 2.39 & .899 \\
My home is a nice place to live & 512 & 2.81 & .836 \\
My parents pay attention to me & 512 & 3.18 & .845 \\
\hline
\end{tabular}

Source: Researcher's analysis

From the responses in Table 3, parents with secure parental attachment style were evidenced from majority of the students who indicated that their parents accept them as they are with a mean of 3.20. This was also evidenced in another 3.18 who agreed that their home is a nice place to be. Another majority of the students with a mean of 3.10 also indicated that they trust their parents. Also as was indicated by a mean of 2.85 students confirmed that their parents would always ask if they know that something is bothering them. Further the study found that parents who are securely attached to their children usually know where their children are and who they are with. This was indicated by a mean of 2.81. Respondents also confirmed that their parents care about them and can always tell when they are upset with a mean of 2.78 .

The responses further indicated that the parents with secure attachment style can easily tell when their children have a problem with a mean of 2.78 . The study also found out that these parents pay attention to their children (2.75) and their children trust that the parents can help them out with their problems (2.74). It was also revealed that the students who are securely attached to their parents have confidence in their parents and feel that their parents respect their feelings (2.70) and listen to what they have to say (2.51). Finally the respondents also confirmed that they share their thoughts and feelings with their parents with a mean of 2.39. These responses indicate that the students are comfortable in the presence of their parents and that they consider their parents as friendly people with whom they share their feelings.

\subsection{Deviant Behaviour (Drug Use and Violence)}

The students also filled the deviant behaviour scale and their reponses were as captured in table 4 . 
Table 4. Students' Responses on the Deviant Behavior Scale.

\begin{tabular}{llll}
\hline Descriptive Statistics & & Mean & Std. Deviation \\
\hline & N & 2.98 & 1.347 \\
I Have lied to Adults & 512 & 1.96 & 1.016 \\
I have used cocaine or heroin & 512 & 2.13 & 1.011 \\
I have fought an adult & 512 & 2.42 & 1.102 \\
Damaged or destroyed public or private property & 512 & 2.19 & 1.157 \\
Used alcohol or bhang & 512 & 2.21 & 1.083 \\
Skipped school for several days without parent's knowledge & 512 & 2.20 & 1.912 \\
Sold drugs & 512 & 2.43 & 1.216 \\
Skipped classes becauseI don't feel like & 512 & 2.10 & 1.093 \\
Carried a weapon to school (knife, pistol) & 512 & 2.36 & 1.092 \\
Fought in class or in school & 512 & 2.11 & 1.068 \\
Been to school or class after drinking alcohol & 512 & 2.12 & 1.096 \\
Planned to destroy school property & 512 & 2.13 & 1.075 \\
Planned to/ burn school building & 512 & 2.02 & 1.047 \\
Carried alcohol or any other drug to school & 512 & & \\
\hline
\end{tabular}

Source: researcher's analysis

From Table 4 above a number of students have confirmed being involved in various deviant activities. For example, majority confirmed that they have lied to adults with a mean of 2.98 and another 2.43 agreed that they skipped classes because they didn't feel like. According to the findings of this study, participants indicated that they had destroyed public or private property with a mean of 2.43 . Further still learners confirmed having fought in school and skipping school for several days without parents' knowledge with a mean of 2.36 and 2.21 respectively.

The study revealed that learners sold drugs at a mean of 2.20 and used alcohol or bhang at a mean of 2.19. Other participants confirmed that they had burnt or planned to burn school building at a mean of 2.13, planned to destroy school property at a mean of 2.12 and had been to school after drinking alcohol at a mean of 2.11. It was also confirmed that some participants had carried weapons to school ata mean of 2.10 , fought adults at a mean of 2.13 , carried alcohol or any other drug to school at a mean of 2.02 and finally used cocaine or heroin at a mean of 1.96 .

\subsection{Irresponsible Sexual Behavior}

Irresponsible sexual behaviour was measured using the interest emotions and relations scale. The students' responses were as depicted in table 5.

Table 5. Students' Responses on Interests Emotions and Relations Scale.

\begin{tabular}{lll}
\hline & N & Mean \\
\hline I have already had sex with boy or a girl & 512 & 2.90 \\
I have a child at home & 512 & 2.05 \\
I plan to wait to get someone I love before having sex & 512 & 3.34 \\
I find it difficult to say no to sexual advances from the opposite sex & 512 & 2.85 \\
I would not wish to have a sexual relationship before finishing school & 512 & 3.48 \\
I plan to have sex as soon as the opportunity arises & 512 & 2.47 \\
I have sex with my boyfriend because I fear he might leave me & 512 & 1.214 \\
\hline
\end{tabular}

Source: researcher's analysis

From table 6, the students have admitted to being involved in irresponsible sexual behavior. At a mean of 3.34 the learners indicated that they are waiting to find someone they love before theycan have sex. Another group of learners also confirmed having had sex at a mean of 2.90. Further still others confirmed that they have difficulty saying no to sexual advances from opposite sex at a mean of 2.85 , planning to have sex as soon as the opportunity arises at a mean of 2.47 , having sex because they fear being rejected at a mean of 2.29 and finally having children at home at a mean of 2.05. However, majority of the learners at 3.48 would not wish to have sexual relationships before finishing school.

\subsection{Correlation Between Secure Parental Attachment and Deviant Behavior}

A two tailed Bivariate Pearson correlation was conducted to test the null hypothesis "There is no statistically significant relationship between secure parental attachment and deviant behavior among secondary school students in Homabay County." The results were as shown in Table 6. 
Table 6. Correlation between secure parental attachment and deviant behavior.

\begin{tabular}{llll}
\hline & & Secure Parental Attachment & Deviant Behavior \\
\hline & Pearson Correlation & 1 & $-.633^{* *}$ \\
Secure Parental Attachment & Sig. (2-tailed) & & .000 \\
& $\mathrm{~N}$ & 512 & 512 \\
& Pearson Correlation & $-.633^{* *}$ & 1 \\
Deviant Behaviour & Sig. (2-tailed) & .000 & 512 \\
& $\mathrm{~N}$ & 512 & 512 \\
\hline
\end{tabular}

**. Correlation is significant at the 0.05 level (2-tailed).

Source: researcher's analysis

The Pearson Product-Moment correlation result indicates a significant negative correlation between secure parental attachment and deviant behavior among secondary school students in Homabay County, with $(\mathrm{r}=-.633, \mathrm{p}<0.05)$. This implies that when children are securely attached to their parents they are less liey to engage themselves in deviant behavior. These results corroborate with those of Lim [15] who also found a significantnegative relationship between parental attachment and adolescents' delinquency. Similarly, Robin [32] also reported that adolescents who exhibit secure attachment do not involve themselves in risky behavior. Cheng [8] reported that parent child relationship is one of the factors that contribute to student deviant behavior.

In the same vein, Misbahi and Aisha [19], found a significant negative relationship between parental attachment and aggression. Sane [35] revealed that attachment insecurity is related to externalizing problem behavior similar to Shek [36] who also reported that strong family bonding protects students from engaging in problem behavior. The findings of this study are also confirmed by those of Beck [3] who found that adolescents with more secure attachment had higher levels of social support from friends. In addition, Jayaram and Caeiro [14] also revealed that improper parenting styles lead to deviant behavior among students. Other studies whose findings also agree with the findings of this study include Ruedisueli [33] who reported that those students who reported that their mothers know their friends had reduced probability of having sex, Guilamo [11] who reported that emotional qualities of the father adolescent relationship were significantly associated to adolescent sexual behavior.

Borhani [4] also reported a positive relationship between insecure attachment and substance abuse. Mutie [22] reported that those who experience emotional parental neglect also express hatred for school rules and elders and report having engaged in different forms of indiscipline in school. Poipoi, Agak and Kabuka [28] are also in agreement with the findings of this study as they also reported that poor relationship between parent and child are some of the home factors contributing to violent behavior among adolescents. Further still, Changalawa [6] reported a significant relationship between parenting styles and alcohol abuse among college students and Dimbuene and Defo [9] found that the quality of parent youth relationship significantly reduces the odds of risky sexual behavior. Finally Negeri [23] revealed that youths with high family connectedness were less likely to commence early sexual activity and to have multiple sexual partners.

\section{Conclusion}

In conclusion, the study found a strong negative correlation between secure parental attachment and deviant behavior among secondary school students in Homabay County. The students who are securely attached confide in their parents whenever they have a problem, they also make sure that their parents are aware of their whereabouts and who their friends are and therefore minimize their chances of engaging in deviant behavior. Since these children consider their parents as their friends they desist from deviant behavior because they fear disappointing their parents. These students also enjoy the company of their parents and so consider their homes as nice places to be. Consequently, they exhibit peaceful coexistence with other people.

\section{References}

[1] Akwalu, A. G. M. (2016). Behavioural Effects of Parental Violence onLearners' Academic Performance in Secondary Schools in Tigania East Sub-County of Meru County in Kenya. Developing Country Studies www.iiste.org. Vol. 6, No. ISSN 2224-607X (paper) ISSN 222-50565.

[2] Banda, M. \&Mweemba, G. (2016). The Nature of Deviant Behavior Patterns that are Prevalent among Pupils in Secondary Schools in Zambia: a Case of Central Province. International Journal of Humanities Social Sciences and Education. (IJHSSE). Vol. 3, Issue 10: 57-64.

[3] Beck, M. K. (2011). The Role of Mothers' Authoritative Parenting in Adolescents Attachmentand Social Relationships. www.drum.lib.umd.edu/bitstream/1903/115.

[4] Borhani, Y. (2013). Substance abuse and insecure attachment styles: a relational study; LUX: A journal of Transdisciplinary Writing and Research from Claremont Graduate University: Vol. 2 Iss. 1 Article.

[5] Bowlby, J. (2008). Attachment. Basic books.

[6] Changalawa, C. N., Ndurumo M. M., Barasa L. P. \&Poipoi, W. M. (2012). The Relationship between Parenting Styles and Alcohol Abuse among College Students in Kenya. Greener Journal of Educational Research. Vol. 2 (2): 013-020 ISSN 2276-7789.

[7] Chebukaka, R. N. (2014). Drug Abuse among Students in Public Secondary Schools in Kenya. The Case of VihigaCounty. International J. Soc. Sci. \& Education. Vol. 4 issue 3, ISSN: 2223-4934 E and 2227-393X Print. 
[8] Cheng, J. (2012). The Effect Factor for Students' Deviant Behavior. The journal of humanResource and Adult Learning. Vol. 8 No. 2.

[9] Dimbuene, T. Z. \&Defo, K. B. (2010). Risky Sexual Behavior among Unmarried Young People in Cameroon. Another Look at Family Environment. J Biosoc. Sci., 43, 129-153 doi: 10.1017/S002/93201000063.

[10] Ekpo, T. E. \& Ajake, U. E. (2013). Family Socio Economic Status and Delinquency Among Senior Secondary School Students in Calabar South, Cross river state, Nigeria.

[11] Guilamo-R. V., Alida B., Lee J., MCcarthy, K., Shannon, L. M., Pitt-Barnes S., \&Dittus P. (2012). Paternal Influences on Adolescent Sexual Risk Behaviors; A Structured Literature Review. Pediatrics Vol. 130/ Issue 5.

[12] Harrison, M. K. (2013). Community Violence Exposure among Underprivileged Adolescents; What are the Buffering Effects of Family Qualities on Negative Outcomes.

[13] Imtiaz, S. \&Naqvi, I. (2012). Parental Attachment and Identity Styles among Adolescents: Moderating Role of Gender. Pakistan Journal of Psychological Research. Vol. 27. No. 2: 241-264.

[14] Jayaram, B., \&Caeiro, D. (2017). Teachers' Perception about Students Indulging in DeviantBehaviour. The International Journal of Indian Psychology. ISSN 2348-5396 Vol. 4, Issue 2, No. 93, DIP: 18.01.130/20170402 ISBN: 978-1-365-78193$3 \mathrm{http}: / /$ www.ijip.in

[15] Lim, J. C., Muslihah, H., Sa' Odah, A. \& Wu, S. L. (2013). ParentalAttachment, Peer Attachment and Delinquency among Adolescents in Selangor, Malaysia. Asian Social Science Vol. 9, No. 15 issn: 1911-2017.

[16] Malayi, A. O., Mauyo, L. W., Nassiuma, B. K., Oduma, R., Majanga, E. K., \&Mandilla, K. L. L (2013). The impact of parenting styles on acquisition of deviant behavior among childrenaged 8-18 years in western Kenya. Global Advanced Research Journal of Management andBusiness Studies (ISSN: 2315-5086). Vol. 2 (10): 496-501. http://garj.org/garjmbs/index.htm.

[17] Mbuthia, W. W. (2013). Perceived Factors Influencing Deviant Behavior Among The Youth in Njathaini community Nairobi http://irlibrary.ku.ac.ke/handle/123456789/9044.

[18] Mertens, D. M (2010). Research and Evaluation in Education and Psychology: Integrating Diversity with Quantitative, Qualitative and Mixed Methods. Journal of Mixed Methods Research 4 (1) 3-5. DOI: 10.1177/1558689809358406.

[19] Misbahi, A. \& Aisha, Z. (2011). Parental Attachment, Parental Acceptance and Aggression among Adolescents. Pakistan Journal of Psychology. Vol. 42 Issue 2, p1.

[20] Msidze, E. \& Defo, K. B. (2013). Effects of Parenting Practices on Sexual Risk Taking among Young People in Cameroon. BMC Public Health 13: 616 https://doi.org/10.1186/1471-2458-13-616.

[21] Mugenda, O. M. \&Mugenda, A. G. (2003). Research methods; quantitative and qualitative approaches. Nairobi African Centre for Technology Studies.

[22] Mutie, J. (2015). Effects of Emotionally Absent Parents on the Behavior of Adolescents inSelected Secondary Schools in
Machakos County-Kenya. http://irlibrary.ku.ac.ke/bitstream/handle/123456789/14414.

[23] Negeri, L. E. (2014). Assessment of Risky Sexual Behaviors and Risk Perception amongYouths in Western Ethiopia: The Influences of Family and Peers: a Comparative CrossSectional Study. BMC Public Health 14: 301 https://doi.org/10.1186/1471-2458-14-301.

[24] Ngai, S. S. (2015). Parental Bonding and Character Strengths among Chinese Adolescents in Hong Kong. International Journal of Adolescence and Youth. Vol. 20 issue 3.http://dx.doi.org/10.1080/02673843.2015.1007879.

[25] Ngwiri, B. M., Mukulu, E. J., Mputhia, G. J. (2016). Influence of Knowledge Technology Transfer on the Growth of Micro and Small Catering Enterprises in Nairobi County Kenya. International journal of scientific and research publications vol. 6 issue1 ISSN: 2250-3153.

[26] Njagi, I. D. (2012). Intimate partner violence among students of the University of Nairobi.

[27] Parks, A. B. (2013). The Effects of Family Structure on Family Delinquency. Electronic Theses and Dissertations.paper 2279. http://dc.etsu.edu/etd/2279.

[28] Poipoi, W. M., Agak, O. J. \&Kabuka, K. E. (2011). Perceived Home FactorsContributing to Violent Behavior among Public Secondary School Students in Western Province, Kenya. Journal of Emerging Trends in Educational Research and PolicyStudies 2 (1): 30-40. Scholarlink research institute journals, 2011 (ISSN: 2141-6990).

[29] Potard, C., Courtois, R., Reveillere, C., Brechon, G., \&Courtois, A., (2014). The Relationship between Parental Attachment and Sexuality in Early Adolescence. International Journal of Adolescence and Youth. Vol. 22 issue 1.

[30] Privitera, G. J. \& Wallace, M. (2011). Research Methods for Behavioural Sciences.

[31] Rafiq, W. M. H., Fatima, T., Sohail, M. M., Saleem, M.\& Khan, A. M. (2013). Parental Involvement and AcademicAchievement: A Study on Secondary School of Lahore Pakistan. International Journal of Humanities and Social Science vol 3. No. 8. (special issue-2013).

[32] Robin, E. Y. (2013). The influence of Parent Child Attachment Relationships and Self Esteem on Adolescents' Engagement in Risky Behaviors.

[33] Ruedisueli, A. (2010). Parental Attachment and Sexual Risk Behavior among Adolescents. Wayne State University Dissertations. Paper 113: http://digitalcommons.wayne.edu/oa_dissertations.

[34] Sanches, C., Pereira, G. M., Moroco, J, Gomes, H. \& Roncon, F. (2016). Deviant Behavior Variety Scale: Development and Validation with a Sample of Portuguese Adolescents. Psicologia: Reflexao e Critica 29: 31.

[35] Sanne, L. A., De V., Hoeve, M., Stams, G. J. J. M., \& Jessica, J. A. (2016). AdolescentParent Attachment and Externalizing Behavior: The Mediating Role of Individual and SocialFactors. Journal of Abnormal Child Psychology 44: 283-294.

[36] Shek, T. L D., Ma, M. S C. \& Tang, Y. P C. (2012). Delinquency and Problem Behavio Intention among Early Adolescents in Hong Kong: Profiles and Psychosocial Correlates. Int J Disabil Hum Dev 2012; 11 (2): 151-158. 
[37] Simba, O. N., Agak, O. J. \&Kabuka, K. E. (2016). Impact of Discipline on Academic Performance of Pupils in Public Primary Schools in Muhoroni Sub County, Kenya. Journal of Education and Practice ISSN 2222-1735 (Paper) ISSN 2222288X (online). Vol. 7, No. 6.

[38] Tadesse, G. B., Mitikie, M., Yemane, B., Amenu, W., \&Tesfaye, C. (2016). Determinants of Risky SexualBehaviour Among Preparatory School Students in Gurage Zone, SNNPR, Ethiopia (A Cross-Sectional School Based Study), Science Journal of Public Health. Vol. 4, No. 4, 2016: 330-341. doi: 10.11648/j.sjph.20160404.2.
[39] Waithima, C. (2017). Substance Use Assessment among School Going Adolescents in Kenya. African Journal of Clinical Psychology. Vol. 1 23-35.

[40] Watiri, L. W. (2012). Factors Contributing to Deviance among Secondary School Students in Miharati Division, Kipipiri District Kenya. http://erepository.uonbi.ac.ke:8080/handle/123456789/4382.

[41] Yesu, L. \& Hardwood, A. E. L. (2015). Effects of Parental Involvement, Support and Pressure on Athletic Participation. River Academic Journal vol. 11, number 1. 